\title{
The Biblical Image of the Providential Ruler in the Protestant Propaganda on the Eve of the French Wars of Religion
}

\author{
Andrei Constantin Sălăvăstru
}

check for updates

Citation: Sălăvăstru, Andrei Constantin. 2021. The Biblical Image of the Providential Ruler in the Protestant Propaganda on the Eve of the French Wars of Religion. Religions 12: 596. https://doi.org/10.3390/ rel12080596

Academic Editor: Scott E. Hendrix

Received: 29 June 2021

Accepted: 28 July 2021

Published: 2 August 2021

Publisher's Note: MDPI stays neutral with regard to jurisdictional claims in published maps and institutional affiliations.

Copyright: (C) 2021 by the author. Licensee MDPI, Basel, Switzerland. This article is an open access article distributed under the terms and conditions of the Creative Commons Attribution (CC BY) license (https:// creativecommons.org/licenses/by/ $4.0 /)$
Department of Social Sciences and Humanities, Institute of Interdisciplinary Research, "Alexandru Ioan Cuza" University of Iasi, 700057 Iasi, Romania; andrei.salavastru@uaic.ro

\begin{abstract}
French Protestantism has remained famous in the history of political thought mostly for its theories regarding popular sovereignty and the right of the people to resist and replace a tyrannical ruler. However, before the civil wars pushed them on this revolutionary path, French Protestants stressed the duty of obedience even in the face of manifest tyranny. The reasons for this were ideological, due to the significance placed on St. Paul's assertion that all political power was divinely ordained, but also pragmatic, as Calvin and his followers were acutely aware of the danger of antagonizing the secular authorities. More importantly, they were fervently hoping for the conversion of France to the Reformation and, in their mind, the surest way such a process could take place was through the conversion of the king and the royal family. Therefore, Protestant propaganda of that time constantly urged the most important French royals to convert to the Reformation, and, for this purpose, they deployed a language full of references to the pious Biblical rulers who led their people towards the true faith-whom the addressees of these propaganda texts were advised to emulate, lest they incur God's wrath. This paper aims to analyze the occurrences and the role of these references in the Protestants' dialogue with the French monarchy.
\end{abstract}

Keywords: France; Calvin; Reformation; kingship; Bible

\section{Introduction}

The sixteenth century has been a crucial period for the development of European political thought, with many historians placing in this age the origin of key modern concepts, such as constitutionalism or popular sovereignty. In particular, the Reformation has been associated with promoting the people's political rights against the unbridled power of the emergent absolute monarchy: this was a rather surprising turn of events, because, initially, it was the farthest thing from the intentions of both Luther and Calvin. The two reformers sought the cooperation of the lawful authorities and this was reflected in their repeated injunctions that all constituted authority must be obeyed. The movements started by them all over Europe followed their lead, but, under the pressure of events, they came to reconsider their original position and adopted a more defiant attitude in the face of lay authorities in cahoots with the Catholic Church and which were seeking their suppression. The historiography dedicated to the evolution of the Reformation in France and to the French Wars of Religion has focused more on the "anti-royalist" phase of Protestant political thought, which produced a polemical literature of exceptional quality which remained in history under the name of the "monarchomach" texts. The beginnings of the French Reformed Church have been the subject of several exceptional monographs: first, Robert Kingdon's Geneva and the Coming of the Wars of Religion in France, 1555-1563 and Geneva and the Consolidation of the French Protestant Movement, where professor Kingdon argues that Calvin and the Genevan Company of Pastors played a fundamental role in the growth and then in the political enterprises of the French Reformed Church; second, Hugues Daussy's Le Parti huguenot: Chronique d'une désillusion (1557-1572), where professor Daussy argues brilliantly that the French Protestants sincerely believed in the possibility of the conversion of France to the Reformation and mobilized all their resources, material 
and spiritual, for this purpose. Hugues Daussy refers in his book to many of the texts by which the Protestants hoped to persuade the king and other grand figures of the realm to join their cause, but focuses more on issues of dating and authorship, without subjecting all the texts to an in-depth analysis in light of Protestant political ideology. This paper aims to complement professor Daussy's research by examining the figure of the providential ruler as it appears in Protestant propaganda directed at the French royal family and the Biblical imagology employed to support that picture.

\section{Results}

\subsection{The Historical Context}

The most infamous event of the French Wars of Religion, which they became forever associated with, is the massacre which occurred during the night of Saint-Bartholomew, on 23-24 August 1572, when Protestants gathered in Paris for the wedding of Henry de Navarre were slaughtered by royal troops and the Parisian population. The massacre quickly spread through the French provinces and it dealt a deathblow to the growth of Protestantism in France. It represented the culmination of a growing hostility between the Valois monarchy and the Huguenot party, which led to a (finally) open breach between them, after years of conflict during which the Huguenots claimed that they were not actually rebelling against the Crown, but against the king's evil advisors. By striking at the Protestant leadership, King Charles IX and his council likely hoped to destroy for good what was for them a troublesome faction. However, the manner in which this attack was carried out, and the subsequent escalation of what was intended to be a political assassination to a wholesale and indiscriminate slaughter of any Protestants the frenzied Catholic crowds could get their hands on, exposed the king to accusations of perfidy and tyranny: in the aftermath of the massacre, Protestant polemicists published constitutional theories meant to provide solutions against royal overreach. Yet, this development had been both unforeseen and unwelcome for the Protestants: previously, they had constantly stressed their loyalty to the Crown, even when waging war against it, and had always rejected accusations of sedition. Putting aside the theological influence of Saint Paul's Epistle to the Romans, which argued that all power was divinely ordained and, therefore, obedience was the duty of all Christian faithful, the militant character of the Calvinist movement was the main reason why Calvin and his colleagues constantly tried to co-opt the French monarchy: as Hugues Daussy brilliantly argues in his book Le Parti huguenot, Calvin and the Huguenots fervently wished for the conversion of France and, in their opinion, this could take place only through the conversion of the French royal family.

When Protestantism started to make its first inroads into France during the 1520s, it was met with the hostility of the Parlement of Paris and of Sorbonne, which took the lead in the persecution of the Reformed faith. While hesitant in the beginning, king Francis I joined these efforts in earnest after the "affair of the placards" from 17 to 18 October 1534, when broadsheets attacking the Catholic mass were posted in major French cities: the king took this event as a challenge to his authority and what followed was a recrudescence of arrests, executions and anti-Protestant edicts. Calvin personally deplored the "affair of the placards", feeling that the recklessness of a few endangered the survival of the Reformation in France. Despite the persecution, though, which increased in intensity during the reign of Henry II (1547-1559), the Reformed faith continued to grow and started to become a truly mass movement during the 1550s, especially after 1555, when the Protestant communities in France started to organize themselves as official churches. Calvin's role in this has been the subject of a historiographical controversy: Etienne Trocmé went as far as to argue that the Protestant leader tried to delay this development, because he feared it could be damaging to his outline for the conversion of France, which consisted of winning the king over and persuading him to carry out the reform of the Church himself (Trocmé 1959, pp. 163-64). Robert Kingdon, on the other hand, favored a much more active role for Calvin and Geneva, asserting that the pastors sent from Geneva "managed to organize religious discontent in France into a militant church in less than a decade" (Kingdon 2007, 
p. 14). Hugues Daussy takes a middle way between the two opposing opinions, suggesting that these two hypotheses, apparently contradicting each other, represent two phases in Calvin's attitude on the matter, going from fear of antagonizing the king, like the affair of the Placards did twenty years before, to a more enthusiastic support for the multiplication of the Reformed Churches (Daussy 2015, p. 26). Regardless, what is undeniable, and what Daussy, Kingdon and Trocmé can all agree on, is that Calvin expected the conversion of France to occur from above, at the command of the king himself. This opinion was shared by his closest collaborators, such as Theodore Beza, who, in a letter to Bullinger from 1556, expressed the same idea (Daussy 2015, p. 29). Their determination to win the king over was due to the fact that, as David Bryson noted, "the application in Calvinism of the sacred biblical principles, set down in Matthew 16: 18-19, of the 'power of the keys' (the power of the church) and the 'power of binding and loosing' (to forbid and to permit) in its dedication to establish 'the true Kingdom of Christ' on earth, and to overturn 'the kingdom of Antichrist', made of the early Reformed churches of France a movement whose ecclesiastical jurisdiction was inseparable from the civil jurisdiction of a legitimate Christian monarch" (Bryson 1999, p. 25). Just like in Geneva, the reformation of the Church in France needed the "magistrate", in this case, the king, to act as a lay enforcer of the rules of doctrine set by the national synod.

Calvin's innermost conviction was that the truth of the Gospel could not but prevail: for him, divine providence was the prime mover of events, as testified by the Bible. Hugues Daussy convincingly points out that "this conception of providence, shared by Calvin's disciples, is connected with the identification they established between the faithful of France and the people-elect of the Bible" and "the connection established by Calvin between the Old and New Testament explains this tendency. Calvin considered that, in the Scriptures, there is only one and the same Covenant, promised to Adam, concluded with Abraham and renewed by the blood of Christ. [ ... ] There is thus a continuity between Jews and Christians ( ...) and the omnipresence of the arguments and references taken from the Old Testament in Protestant rhetoric derives from this spiritual connection" (Daussy 2015, pp. 29-30). French Protestants regarded themselves as the new people-elect, which was fated to endure similar trials to those experienced by the Israelites of the Old Testament: just like their predecessors, they were also destined to prevail, because they were the ones upholding the truth of God's law against the idolatrous "papists". Additionally, just like the Old Testament featured frequently all kind of providential characters who pushed forward God's plan, so does the Protestants' propaganda constantly invoke their figures in the hope that they could find and persuade a contemporary equivalent who could restore the Church of God to its initial purity. In this regard, David represents the quintessential model of a godly king whom the sixteenth-century monarchs were urged to emulate. Second to him, we have the figure of Josias, king of Juda and author of a religious reform of the kind the Protestants hoped that the king of France could lead. From the non-monarchical personalities of the Old Testament, Moses features prominently. Those rulers who disobeyed God are also referred to frequently, as a cautionary tale for the contemporary princes: but, unlike the monarchomach literature which appeared around 1572 and afterwards, the emphasis is on God's chastisement of such rulers, without any significant suggestions that the people could assume this role itself. The Protestant political thought of this period is loyalist: the intent of their propaganda is to warn, not threaten.

\subsection{The Protestants and Henry II's Persecution}

The Protestants' hope that the king could be persuaded to embrace their cause was severely put to the test in 1557 by the so-called "affair of the rue St. Jacques", when a clandestine Protestant religious service was discovered by the population of Paris and a significant number of the participants were arrested by the authorities: the importance of the event was that it brought to light the fact that the Reformation was gaining adepts amongst the higher strata of the society, something which profoundly shocked the king and his council. Amongst those arrested, there were many members of the nobility and the 
reaction of the king was accordingly harsh: a special tribunal was instituted in order to try the captives and the sentences were correspondingly severe. Henry II had obviously considered the presence of nobles amongst those arrested as a personal affront and used this opportunity to make clear to everyone his determination to root out heresy. Robert Knecht argued that the affair gave the Protestants "unwelcome publicity" and made them wonder "how should they react to persecution by the Crown": Calvin's opinion was that "prayer was their only recourse" and "it would be preferable for them all to die than that the Gospel should be accused of fomenting sedition" (Knecht 2014, p. 52). Yet, despite the king's attitude, the Protestants appealed to him in several texts: a letter to the king, a "remonstrance" and a tract called "Apologie ou defence des bons chrestiens", all published anonymously.

The text of the remonstrance is summarized by Jean Crespin in his Histoire des martyrs. The declared purpose of the remonstrance is to "soften the king's heart, have him listen to their cause and reject the poor opinion the king had of them, which had been instilled into him maliciously" (Crespin 1887, p. 547). This argument will become the mainstay of Huguenot propaganda, especially that issued from the high circles of the nobility, during the first three religious wars, between 1562 and 1570. It is also a common medieval trope: the king cannot be the source of anything evil and its true cause must lie outside his person. The Protestants, through the voice of Calvin, were already casting the cardinal of Lorraine into the role of "chief architect of repression", thus avoiding "implicating the king directly" - a role which later "became embroidered into their story of resistance to persecution and formed an essential part of the black legend of the Guise" (Carroll 2009, p. 93). The remonstrance establishes a parallel between the "calumnies" spoken of the Protestants and the accusations launched against the Christians of the early Church. The only motivation of their enemies is their cupidity, to keep the riches they had unjustly usurped from the Church. The theme of the "false accusations" reveals one key issue of the religious strife in France which led to the Wars of Religion: namely, in the words of Wylie Sypher, the "characterization of Protestantism as 'pretended' religion, religion 'deformed' rather than reformed". This "referred not simply to erroneous doctrine but to a form of moral depravity which originated in personal vices and which threatened to plunge France, as it already had Geneva, into collective criminal anarchy" (Wylie Sypher 1980, p. 60). This was a problem which the Protestants constantly struggled against, as nothing could have been more damaging to their reputation, both amongst the ruling circles and amongst the wide population: hence, the Protestant polemicist stressed the falsity of such charges and deployed for this purpose the parallels with the fate of the early Christians. The king is cast in the role of arbiter and thus advised not to take these accusations for granted, but instead carry out a thorough investigation, which could have no other outcome but the exoneration of the Protestants: it would thus be revealed that the only purpose for the gathering of the Rue St. Jacques was to pray for the king and his kingdom. The king's only fault was being unaware of the truth and, in this, the Protestants were not that far from reality: in the words of Stuart Carroll, Henry II referred to the French Calvinists as Lutherans, "revealing his ignorance of some of the basic theological issues" (Carroll 2009, p. 94). Yet, the Protestants had totally misread the king's attitude: regardless of his unfamiliarity with Calvinist doctrine, Henry II was violently hostile to all that the Catholic Church deemed heresy. The author of the remonstrance seemed to believe that, in order to expose the reality, the king should organize a debate between Reformed divines and the "Sorbonnistes"; in such circumstances, Henry II could not fail to recognize the godliness and the righteousness of the Protestant cause. Such a scenario, though, was hopelessly naive, as will be proven by the Colloquium at Poissy in 1561 and, later, by the behavior of the future Henry IV, a former Protestant himself, who did organize a debate of this kind in 1600-and granted the Catholics the victory (Babelon 2010, p. 605).

The Apologie has for its purpose to disculpate the Protestants of the accusations brought against them: for the author, it is not just a matter of the physical safety of the faithful, but also a religious duty, because "in the person of the Protestants, the name of God is 
blasphemed and the holy doctrine vilified by impudent calumnies" (Crespin 1887, p. 548). The persecuted figure of David, from the days before he became king, is deployed in the text as the archetype of the persecuted Reformed faithful: the defamation of his character was regarded as worse than all material deprivations because it was also an attack against God and it is this that all efforts must be directed against with the help of God. A direct lineage is established between the experience of David, that of early Christians and of contemporary Protestants: persecution has always been the lot of the God's faithful. If there is this direct connection between the Apostolic Church and the Reformed faith, then the patristic arguments against the repression of the ancient Christians could also be appropriated by the Protestants and brought forward before the king: Tertullian, Justin Martyr, Cyprian, Arnobius, Minucius Felix, Hilary of Poitiers, Eusebius of Caesarea are the authorities cited for this purpose. The prospect of being severely judged by posterity is brought up by the author of the Apologie, when he reminds the king that the persecuting pagans had been condemned for their deeds. Ignorance cannot be an excuse, because the similarity between the behavior of early Christians and that of contemporary Protestants should be obvious for everyone: they all gathered in secret, at night, because they were forced to do so by hostile authorities. What would otherwise be considered illicit behavior is thus transformed by the author into a reason for pride and proof of their innocence. Not only are the outrages suffered by the Protestants unjust, but they are also denied the opportunity to defend themselves: that is a clear allusion to the king's role as provider of justice in his realm, which had always been the first duty of a monarch from the early Middle Ages and one which the French kings in particular had been strongly associated with. If the Protestants were not heard, then the king would have failed in his role. The author complains bitterly of the popular hatred against the Reformed faith and makes God's potential vengeance loom over the people. The obedience of the Protestants, submitting to their king even in the face of persecution, is strongly contrasted with the unruliness of the anti-Protestant crowds, who, by taking matters into their own hands, are interfering with the normal course of the king's justice. For the author, those accusing the Protestants had absolutely no moral grounds for their actions: the moral turpitude of the Catholic clergy was, in the opinion of the author, well-known and disproved the charge that the Protestants' secret gatherings were places of debauchery. However, the association with the Christians of the apostolic age does not imply only the promise of a final triumph, it also imposes upon the Protestants the obligation to imitate the behavior of their celebrated forerunners: they must defy all persecutions and stand firm on the side of the truth of God.

If the remonstrance and the Apologie remained extremely respectful towards the king, in the belief that, if Henry II agreed to organize a debate between Catholic theologians and Protestant pastors, the king would undoubtedly see that the truth was on the side of the Reformation (Daussy 2015, pp. 49-50), the letter was written in a more menacing tone, reminding the king that divine vengeance could fall upon him. The letter reflects the author's profound belief that God is on the side of the Protestants and all their enemies were or will be cast down by divine providence. There is no doubt in his mind that the enterprises of the king were successful as long as they were in accord with the goals of the Reformation: whenever that was not the case, God's punishment fell swiftly upon France, as it happened with the defeat at St.Quentin in 1557, which God allowed in order to divert the alleged threat the French commander, the constable Anne de Montmorency, proffered against Geneva in the event of victory. In his opinion, God did not allow that "peace be established for the persecution of his servants", just like "your cardinals were not able to prevent, through their cruelty, the advancement of the Gospel, which has taken such roots in the kingdom that, were God to allow to destroy them, you will be a quasi-king without subjects" (Crespin 1887, p. 540). There is a sharp contrast, for the author of the letter, between the worldliness and riches of the contemporary clergy and the poverty of the clergy of the Bible. Here, the king would have a role to play, namely, to make the clergy "similar to the ancient sacrificer Levites", who "had no lands, or possessions, as Joshua expressly commanded them", or to the "primitive Church, which had flourished and remained pure 
as long as the ministers were simple and did not seek grandeur and private benefits, but only the glory of God" (Crespin 1887, pp. 540-41). In order to reform the Church, the king must confiscate its goods, which will then be used to increase the well-being of his subjects and his own power: the author does not forget to point out that this will lead to the cessation of all payments to Rome, which had always been a point of contention between most Catholic kings and the papacy. The menacing tone from the beginning of the letter is somehow attenuated by the author's protestation against the charge of sedition: while rejecting any association with the radical Anabaptists, "which Satan arouse in our time in order to impede the light of the Gospel" (Crespin 1887, p. 541), the author points out that history proves that conversion to the Faith did not diminish the monarchs who took this step. Both the ancient example of Constantine and the contemporary ones of the king of England and the German Lutheran princes are brought up as evidence for this argument. In truth, Catholic political thought was more prone to accept resistance against princes on religious grounds: this was a weak point in the Catholic argument, which the author does not fail to remind the king of, when pointing out to Henry II the possibility of papal bulls permitting subjects "to chase out their natural princes and lords" (Crespin 1887, p. 541). On the contrary, according to the author, the Protestants had always endured patiently the persecutions they had been subjected to. The only solution for the king of France to put an end to religious strife is to call "a holy and free council", which was to be presided by the king himself and not by the pope, who "must defend his cause only with the help of the Holy Scripture": in doing so, the king would follow in the steps of "the good kings Josaphat, Ezekias and Josias", "chasing out of the Church all idolatries, superstitions and abuses which directly contradict the Holy Scriptures of the Old and the New Testament, placing thus your people in the true and pure service of God, without listening to the words of the papists that these questions had been settled by councils" (Crespin 1887, p. 542). The idea of a reform of the Church by an ecumenical council had been at the forefront of the Protestant movement from its very beginning and traced its roots in the conciliar theories which almost triumphed in the first half of the fifteenth century. By 1557, the Council of Trent, called by the pope, already had its first two phases (in 1545-1547 and 1551-1552), but that was far from what the Protestants had wished. The word "free" was the give away: a council which should be free of papal influence, outside of Italy. Lutherans had asked for a general council on German soil: the Calvinists were thinking of one taking place in France. The idea that the king himself could take the lead in reforming the Church was not entirely new and it resonated with the Gallican sentiments, which were strong especially amongst the Parlements: more than one century before, with the Pragmatic Sanction of Bourges from 1438, Charles VII undertook such a policy, showing, in the words of Hubert Jedin, that France could be "prepared to regulate ecclesiastical affairs in their respective territories with complete independence and without reference to either Pope or Council" (Jedin 1963, p. 20). As pointed out by Alain Tallon, "the Gallican solution to the religious crisis passes through the recognition of the autonomy of the national Churches", an idea later embraced by the cardinal de Lorraine, the most preeminent Catholic prelate in France, himself (Tallon 2002, p. 101).

However, what Calvin and his adherents were expecting was much more than what the Gallicans envisioned and than what the French monarchy, for all its conflicts with the pope, had ever contemplated: the reference to "idolatries" and "superstitions" prove that what they had in mind were significant changes in religious doctrine, not just the elimination of abuses. For the Protestants, "abuses" and "idolatries" are equated, trying to impress upon the king that the eradication of one entailed the suppression of the other: the kings of France had long looked favorably upon the idea of an administrative and moral reform of the Church and, by this equivalence, the hope was that they could be persuaded to also take the ultimate step, namely to support the adoption of Reformed theology. If the king did not heed this advice and persisted in persecuting the faithful like the Pharaoh of the Old Testament, God would take away his crown just like He did 
with “Jeroboam, Nadab, Baasa, Ahab and many other kings who followed men's customs against the command of God" (Crespin 1887, p. 542).

\subsection{The Appeal to Queen Catherine de Medicis}

Obviously, these kinds of arguments had little chance to persuade Henry II, as even some Protestants theologians admitted, despite the hopes of Calvin and others. Under Henry II, the persecution would continue apace, up to a point where the king was ready to sacrifice his foreign policy objectives in order to carry out a fierce repression of heresy: the peace of Cateau-Cambrésis, signed with Spain in 1559, was supposed to free the king's hand so he could focus all his attention on the eradication of Protestantism in France. Henry's death, following a tourney accident, on 10 July 1559 undoubtedly saved the Protestants from a massive intensification of the persecution and was seen by them as God's deliverance of his chosen people. In their view, since Henry proved blind to the truth, God cast him down and it would be his sons and the queen-mother on whom they would focus their efforts in the next years. Since the new king, Francis II, was under the influence of his anti-Protestant in-laws, the duke François de Guise and his brother, the cardinal Charles de Lorraine, the Protestants appealed to Catherine de Medici in two letters, written, according to the analysis of Hugues Daussy, by the pastor François de Morel. Both these letters are summarized in de la Planche's Histoire de l'estat de France, tant de la république que de la religion. During the affair of Rue St. Jacques, Catherine de Medici took under her protection two noblewomen who were part of her entourage (Roelker 1996, p. 232), something to which the author of the letters alludes and undoubtedly made him believe he would receive a favorable hearing from the queen. These texts were written in the context of the "Du Bourg affair", named after Anne du Bourg, the councilor of the Parlement of Paris who was arrested after criticizing the king over the persecution of the Protestants, during a session of the Parlement on 10 June 1559. Henry II died one month later, but $\mathrm{du}$ Bourg remained in prison (and would be executed at the end of 1559). The author points out in the first letter that the Protestants had hoped for the queen's intercession even when Henry II still lived, by imitating the biblical example of queen Esther, who had intervened to her husband, the Persian king, in favor of the Jewish people threatened with extermination (de la Planche 1576, pp. 35-36). The image of Esther played an important role in the political ideology of early modern France because, as argued by Nicole Hochner in a study on the use of this image by Anne de Brétagne, "she champions a moderate and checked kingship where the queen consort herself is the antidote against political abuses" and "offers the example of how a woman, within the bounds of marriage, can play her part in the political arena" (Hochner 2010, p. 758). Now that the king was dead, the author of the letter judged that the situation was more favorable and the queen would be in a better position to help the Protestants (de la Planche 1576, p. 36). The outcome of such an action could only be a promising future for her and her children, whom "God would take care of" and "augment the prosperity of their reign" (de la Planche 1576, p. 36). Despite the rashness of the letter, Catherine promised an improvement in the treatment of the Protestants on condition that they limit themselves to private worship only and avoid public assemblies.

Since Catherine's influence in the royal council, at this time, was little, the promise had no effect. The Guises continued Henry II's policy of persecution, organizing searches and arrests in Paris (Constant 2002, p. 67), which motivated Morel to send her a second letter. The text, as summarized by de la Planche, reveals the bitter disappointment of the Reformers, who had submitted to the queen's request and avoided large public gatherings, yet they were provided no relief for their obedience. The theme of the letter is "the bad faith", a bad portent for the future: the queen's previous promise is treated by the Protestants as a solemn pact, something which no prince could break without consequences. The imprisonment of Anne du Bourg plays a prominent role amongst the Protestant grievances and the queen is reminded that God's punishment could still fall upon her and her children. If her power was secure then, all could change due to the iniquities committed 
under her watch, and the fate of Henry II is considered by the author as conclusive evidence of God's will, which could not be misinterpreted by any person of good faith. However, it is not divine providence alone which could punish an errant prince and the author does not hesitate to point out to Catherine de Medici the real prospect of a rebellion if the procedure against Du Bourg, so unjust, would continue (de la Planche 1576, pp. 65-66). This is one of the few "monarchomach" statements during this period when the Protestant propagandists looked instead to appease the monarchy. Du Bourg himself, on the eve of his execution, "addressed a violent indictment of the monarchy to his judges" and argued that "the king who disobeyed divine commandments ( . . ) was guilty of lèse-majésté against God and 'by this crime deserves the death penalty, if he persists in an error that he should have condemned"' (Christin 1999, p. 205). Du Bourg's words are reminiscent of the doctrines of tyrannicide developed by the Catholic League after 1588-Protestant political theory would never go that far, even in its most "monarchomach" phase. Unlike Du Bourg, who had nothing more to lose, Morel is much more measured in his words. Still, his warning makes a strong contrast with the usual professions of obedience coming from the Protestants: but the author can reconcile these apparently contradictory attitudes by arguing that the indignation aroused by the eventual execution of Du Bourg was not felt by the Protestants alone. On the contrary, it is a sentiment shared by all those angered by the abuses of the papacy (de la Planche 1576, p. 66). Hence, it could not be evidence of the seditious nature of the Protestants if this indignation was felt by every just individual, regardless of his creed. In the opinion of Hugues Daussy, "this violent language is not solely due to the temperament of the speaker: it actually reveals a true belief, connected with a veritable stupefaction at the blindness of the queen-mother, incapable of seeing the evidence that God had already expressed His displeasure by ending the life of Henry II" (Daussy, p. 101). In fact, it could be said that the harshness of the second letter testifies to the emotion stirred both amongst Protestants and Catholics by the case of Anne du Bourg. It greatly concerned the Catholics because it revealed the Protestant sympathies in the Parlement of Paris and, on the other hand, in the opinion of Robert Kingdon, it "did much to strengthen the Calvinist cause", both because of Du Bourg's constancy and due to the "excellent publicity the affair received" (Kingdon 2007, p. 64). Yet, it is without doubt that the hopes which the Protestant pastor placed in the queen rested upon a misinterpretation of her attitude: her apparent religious moderation, which will also manifest itself during her regency, was taken for sympathy towards the Reformation. Obviously, nothing could be further from the truth.

\subsection{The Protestants' Next Best Hope: Antoine de Bourbon, King of Navarre}

Another unexpected turn of events during this period presented the Protestants with a new opportunity, while reinforcing their belief that they were receiving the support of divine providence: Francis II died on 5 December 1560 and his death caused the fall from power of the ultra-Catholic Guise brothers, who had dominated the royal council during his brief reign. As long as they remained influential, there was little hope for the Protestants to make any significant headway, but now, with them out of the picture, the prospects for the Reformation in France became brighter, because the first princes of the blood, Antoine de Bourbon and his young brother, Louis de Condé, seemed in a good position to take control of the government. During the brief reign of Francis II, in an attempt to undermine Guise influence, Protestant polemicists had tried to argue that the king of France was a minor until the age of 25 and he should be subjected to "the oversight of a regency council established by the Estates General and the princes of the blood" (Benedict 2002, pp. 150-51). Not only did this argument fail to make any headway, but Louis de Condé was even arrested and sentenced to death for his alleged participation in a conspiracy against the king-and only the death of Francis II saved his life. With the new king, Charles IX, too young to rule alone, a formal regency had to be constituted and the two Bourbon brothers were entitled to a prominent place in it. Louis de Condé and Antoine's wife, Jeanne d'Albret, had already converted to the Reformation and Antoine, despite his ambiguous attitude, 
was regarded as sympathetic to Protestantism and as a possible convert as well. Calvin had regarded Antoine as the person most entitled to overthrow the Guises from power and had constantly urged him to assert his rights. If the king of France was temporarily unable to heed the call of the reformers, nobody seemed more suitable for Calvin than the first prince of the blood to plead the case of the faithful and make Protestantism triumph. According to Henry Heller, "the support of the aristocracy, and more particularly the princes of the blood, provided the Calvinist community for the first time with indispensable protection, allowing Protestants to remain obedient to at least the lesser magistrates of the kingdom if not to the monarchy itself" (Heller 1986, p. 244). In 1558, Calvin already saw Antoine de Bourbon as a new David (Daussy 2015, p. 68), and, in the crucial period after the death of Francis II, letters, remonstrances and even poetic texts tried to persuade Antoine de Bourbon to take action for this purpose. A 1561 text called Remonstrance en forme de Lettre Missive, à très-illustreet debonnaire prince Antoine de Bourbon Roy de Navarre, written by the Reformed Church of Paris, reminds Antoine that he had enjoyed God's special grace who helped him escape his enemies. From the beginning, the author tries to connect the fate of Antoine to that of the Reformed faith: he was not saved alone, but also together with his kin (an obvious allusion to the deliverance of Louis de Condé), and, more significantly, with "all those who have fear of God" (Mémoires de Condé 1743, p. 320). Antoine, in turn, is God's chosen instrument for the relief of the Protestants and the propagation of the Gospel. It is a sacred mission, obviously inspired by similar instances in the Old Testament of individuals selected by God to further His purpose in the world: therefore, it cannot be rejected without the risk of incurring God's wrath. Antoine cannot "establish his grandeur and maintain his authority" through any human skill, but only with the help of God: for the author, the Old Testament provides clear evidence that this is the case, as "God had always made the kings of Israel who had been faithful to His service thrive", while "He doomed and ruined those who were disloyal to Him" (Mémoires de Condé 1743, p. 321). What the Protestants are expecting in these circumstances from Antoine de Bourbon is not mere relief, but the furthering of their cause: he must surround himself with a Reformed entourage, who will shield him from pernicious influences, and work for "the support and the advancement of the Gospel" (Mémoires de Condé 1743, p. 321).

However, it is not just with divine rewards that the author is trying to entice Antoine de Bourbon to the side of the Reformation: undoubtedly aware of this vacillating personality and of the fact that his ambition might weight for more than the Protestant cause, the author suggests a possible patron-client relationship between Antoine and the Protestant movement. The argument is shrewd, because not only could the Protestants provide the king of Navarre with a base of support which he could ill afford to lose, but abandoning them to their enemies would stain his honor: in the sixteenth-century world, a nobleman could not refuse to help his clients, "loving servants", as the remonstrance referred to the Protestants, without suffering a massive loss of prestige and reputation. The author of the remonstrance obviously counted on this, as he does not hesitate to bluntly point out the consequences if the king of Navarre refused to heed his advice: "the persecution of the faithful, if you will let it continue, will bring discontent to yours, diminish your forces, strengthen the hearts and the courage of your enemies and give birth to hatred and contempt for you in your neighbours" (Mémoires de Condé 1743, p. 321). Antoine de Bourbon is cast in the role of a grand pacificator and such a task could be accomplished by a "general amnesty for all false crimes which had been blamed on each person, for cause of Religion", but an amnesty which "must not benefit only those in obedience to the Roman Church" (Mémoires de Condé 1743, p. 322), otherwise the endeavor would be pointless. This is likely a veiled suggestion for Antoine de Bourbon to take the reigns of the government, because such an edict could have been passed only in the name of the (then underage) king: and, for this purpose, controlling the regency would have been a must. In addition, all commissions harassing the Protestants should be disbanded: the author does not hesitate to point out the possibility of an open rebellion if this did not happen. However, the most daring request of the remonstrance is the suggestion that the 
king himself, Charles IX, be instructed in "the fear of God and knowledge of the Law" so that, when he came of age, he could "govern his people with righteousness, equity and justice", while "all atheists, libertines, blasphemers and despisers of God" must be sent away from the king's side (Mémoires de Condé 1743, p. 324). Despite the fact that Antoine de Bourbon never formally adhered to the Reformation, the remonstrance claims him as one of their own and as Protector of the Reformed Church in France. This is nothing else but a barely veiled program of a Protestant monarchy. If Antoine de Bourbon was to achieve these goals, he "would be another Zorobabel or Esdras", "will restore the Temple of God" and "reestablish His ruined Church" (Mémoires de Condé 1743, p. 324).

Another letter, called Epistre envoyée au Roy de Navarre par les Ministres et Eglise assemblée au nom de Jesus-Christ en la ville de Rouen, also written in 1561, uses similar argumentation. The parallel with the Jewish people captive in Egypt is brought forward from the very beginning: it is a symbol of both the patience with which the Protestants could endure persecution and of their potential delivery by the grace of God, through the agency of a human savior, like Moses. The letter stresses the continuity between the Old and New Testament, by pointing out that the examples the Protestants seek to emulate are the "Patriarchs, Prophets and Apostles". If God had made use in the past of "Judges, Kings and Princes" in order "to withdraw the Church from the hands of tyrants" (Mémoires de Condé 1743 , p. 325), the implication is that the same duty falls upon the contemporary rulers, in this case, upon Antoine de Bourbon. The Christian character of the Protestant faith is also emphasized at length and is contrasted with the accusations made against them, that they "wanted to abolish all reverence for God and the true religion", "upend all world's order, police and honesty", "conspired to live as hideous monsters, enemies of God and all creatures" (Mémoires de Condé 1743, p. 326). The fact that the Protestants are not willing to yield to the pressures of the Catholics is clearly suggested by the analogy (once again) with Christ Himself, Old Testament Prophets and the Apostles: the cause is just, therefore abandoning it in the face of danger would be completely inconceivable. Once again, it is pointed out that the condemnation of the Protestants was against all human and divine law, because they were not offered a chance to be listened to. The prospect of exile is evoked and, thus, to the injustices suffered by the Protestants are added the negative consequences for the kingdom by the loss of so many of its subjects. Yet, the letter is milder in tone than the Paris text: the appeals to Antoine de Bourbon's mercy are repeated again and again, but there is no direct suggestion that, if he failed to act, he would be exposed to divine vengeance.

A third text, Remonstrance aux princes du sang touchant les affaires de nostre temps, written anonymously also in 1561, was formally addressed to the "princes of the blood", which, at that time, meant first and foremost Antoine de Bourbon and his young brother, Louis de Condé. The text opens up with a statement exalting the status of the "magistrates and princes", which "according to the Scripture, are called Gods" (Mémoires de Condé 1743, p. 215). This is an assertion reminiscent of seventeenth-century absolutism and James I's similar claims in his Of the True Law of Free Monarchies. The purpose of the author, though, is not to suggest some sort of unbridled authority for the princes, but to impress upon them the necessity of an absolute devotion to justice: this identification with God meant they must show an equal diligence to protect God's law. The author's opinion on the purpose of political power is Augustinian: the sinful nature of man made government necessary, in order to preserve public peace against "man's nature inclined to evil" (Mémoires de Condé 1743, p. 216). The King of Navarre and his brother have a duty to God both in their role as princes, but also on a more personal level: the author mentions that God "protected you against your enemies" (Mémoires de Condé 1743, p. 216), an obvious allusion to Condé's deliverance from his death sentence, following the passing of Francis II in December 1560. The remonstrance intermingles the sufferings of the Protestants with the misfortunes affecting all of France, something which will be characteristic of Protestant literature during the entire Wars of Religion: the two princes are not supposed to save only their coreligionists, but to act to protect the whole kingdom. Justice for the Protestants 
and the public good are thus joined. There is a short abandonment of the theocentric argumentation in favor of one focused more on the noble tradition of revolt. Jules Racine St. Jacques points out that the Protestant aristocracy felt itself invested with a "duty of the conservation of the French monarchical state in the purity of its traditions" and "explained its discontent by pretending to defend the ancient constitution of the kingdom against the usurpation of the throne by the Guises" (Racine St-Jacques 2012, p. 64). The remonstrance intended to exploit those sentiments. There is also a feeling of eschatological apprehension running through the remonstrance, as the text opines that the second coming of Christ is close: therefore, the faithful must increase their efforts to give a good account of themselves. Ann Ramsey has pointed out that "the religious imagination of the sixteenth century was steeped in prophecy and astrological prediction, eschatological preaching, and a penitential consciousness rooted in preparation for the approaching end of time and the Last Judgment" (Ramsey 1999, p. 160). The examples which the princes of the blood must follow are taken from the Old Testament, like Ezekias and Josias, but also from amongst the Christian Roman emperors, like Constantine and Theodosius. Since all these rulers were traditionally associated with religious reforms and with promoting faith in the Biblical God, the hint for Antoine de Bourbon and his brother was clear. However, the author does not hesitate to go from veiled implication to a direct request, when arguing that "Princes and Magistrates must do their duty in their turn, of defending the members of Jesus Christ, to advance and help His Church, so that the pure Word of God will be announced to the people" (Mémoires de Condé 1743, p. 217). The text becomes here a veritable Protestant political program, as it emphasizes the necessity of measures for correcting the people's vices, laymen and clergy alike: this suggestion was obviously inspired by the situation in Geneva and other cities where the Protestants had been able to take control. The consolidation of the Church (and by that the author obviously has in mind the Reformed Church) could not occur in the absence of this process of true imitatio Christi. The text also asks the addressees to use their influence before the king, but whether this involved attempting to convert Charles IX to the Reformed faith is unclear. There is one reference to the eternal reward due the king "who preserved well the true service of God" (Mémoires de Condé 1743, p. 218), but the remonstrance insists more upon the traditional duties of a monarch, something which even their Catholic opponents could not have disagreed with: protect the kingdom from external enemies and spare the subjects from tyranny and unfair taxes and exactions. Fulfilling these duties will bring the king both God's favor and the love of his subjects. The text ends reminding the princes once more of the high station to which they have been raised by God and of the hopes placed in them, engendered by the "good will which is in you and the affection you have showed for the honor of God and of His Church" (Mémoires de Condé 1743, pp. 219-20). According to the remonstrance, these hopes must not be proven to have been in vain.

Similar arguments are brought up in a poem called "Exhortation de la voix céleste au Roy de Navarre": the text refers to a divine mission which Antoine de Bourbon was called to fulfill, a mission which, we find out later in the text, was nothing more than the conversion of all Christian Europe, which, the author assumed, would follow the example of a converted France. Such a momentous achievement could be realized only by an equally formidable personality, something which Antoine de Bourbon, already famous for his indecision and not being a particularly competent politician, could have never been. Yet, ignoring the truth of the poem's addressee, the rhetoric of the author reaches a fevered pitch when describing Antoine as the summum of all biblical qualities: a David in status, a Solomon in wisdom, an Aaron in advice and a Moses in behavior. The portrait thus drawn is barely human, but the hyperbole was necessary in light of the task envisioned: anything less and the goal of converting France, Italy and Spain to the Reformation would have crushed anyone bold enough to undertake it. The author's point is obviously an appeal to mundane glory, implying that the king of Navarre could become "souz le Roy general chef du monde", "gonfalon de l'Eglise opprimée" and "le guide et support de toutes nations" (Schmidt 1882, p. 16). In light of such tremendous honors, which would have dwarfed 
any of his Bourbon ancestors, what weight would Antoine's actual goal of recovering little Spanish Navarre have? Once again, what was expected from Antoine de Bourbon was to act as a lay religious reformer by banishing all "abuses and idolatry"; the king also had to be co-opted. It is plainly obvious from the text that the Reformers, despite some occasional grumblings, are not yet prepared to openly challenge the French monarchy: Antoine's potential actions, revolutionary as they would be, must have the king's consent. This will be obtained by proving to the young Charles IX that the reform of the French Church after the Genevan model is a "divine work" (Schmidt 1882, p. 17): the author seems to take for granted that a "Most Christian King" like Charles IX could not fail to understand this and his assent could only increase his reputation and the dignity of his title. Yet, God's rewards are destined first and foremost for the king of Navarre, the author likely hoping that this will entice the addressee to heed his advice.

\subsection{A New Young King and the Symbolism of Josias, King of Judah}

The ascent of a young king like Charles IX was already regarded by the Protestants as a promise for a better future. As pointed out by Hugues Daussy, guided by the two Bourbon princes, the king could become a new Josias and relieve the Church of God persecuted by his predecessors and their advisors (Daussy 2015, p. 205). The Reformed propaganda aimed at persuading the young king included a poem called Trois Sonnets au Très-Chrestien Roy de France Charles, which is dominated by the comparison between Charles IX and the Hebrew king Josias. Raised by God to the throne, Charles could be invested, the Protestants hoped, with a similar mission, but for this to happen, the king, of whose young age the Protestants took cognizance, had to be surrounded by a Protestant entourage. Such a role could be fulfilled only by the princes of the blood, Antoine de Bourbon and Louis de Condé, hence all the previous efforts of the Protestant polemicists to convince the former (as Louis needed no urging) to take matter into his own hands and exploit the favorable situation after the death of Francis II to establish his own power for the purpose of furthering the Reformation. Obviously, the Protestants desired to avoid at all costs a repetition of the disastrous situation which emerged during the reign of Francis II as a result of Guise influence and likely hoped that the two Bourbon princes could assume at court, under the new king, a position similar to that previously occupied by the two Guises. Surprisingly, this poem, unlike the majority of the texts addressed to Antoine de Bourbon, does not hesitate to point out the possible negative consequences for the king if Charles IX failed to heed this urging: threatening the king was never the most diplomatic action and it was a solution the Protestants resorted to only in their darkest hours after the affair of Rue St. Jacques in 1557, when Henry II's campaign of persecution seemed fully on the march. However, the threat to Charles IX is still mild: it is not a physical threat, resulting from God's punishment, but, instead, the judgment of posterity. The king's reaction to the hopes placed in him by the Protestants will determine his place in history: he will either be placed together with "the kings without glory", his "memory black and obscure", or his "memory will never be extinguished", because the "good kings' glory and memory is forever" (Mémoires de Condé 1743, pp. 221-22).

The most elaborate text attempting to persuade the king to embrace the Reformation was a polemical piece called Christian Exhortation, preceded by a letter to the queen-mother. The hope of the author, who remains anonymous, but is considered by Hugues Daussy to have been a pastor on the basis of the copious biblical quotations from the text (Daussy 2015, p. 207), is to see the Reformation triumph in France and, he considers the king the person most entitled to accomplish this task, following the example "of good and faithful kings which in their time have done their duty of banishing idolatry from their kingdoms and restore the true and pure worship of God" (Mémoires de Condé 1743, p. 223). The author takes on the mantle of a prophet castigating the impious kings, like the similar figures of the Old Testament: by this analogy, he tries to shield himself against a potential backlash from the offended monarch. Punishing the man speaking the word of God would have invited unflattering comparisons with negative royal figures of the Bible such as 
Jeroboam or Ahab. The persecutor of the prophet is the tyrant, the text clearly reminds the queen-mother, and the implication is that a godly king like Charles IX could not follow such a sinful example. The role Catherine de Medici could play in the reign of her son is illustrated by a host of Biblical references, where the religious virtues of Solomon, David, Ezekias or Josias are attributed to their pious upbringing by their mothers. The image of motherhood is thus brought up to construct a position of authority which a female-queen could not otherwise enjoy in a France dominated by the Salic law, and from this position Catherine could try to use her influence on the king. This rhetorical strategy is consonant with the image Catherine tried to promote about herself: as mother of the king, she may have had a natural authority (something which the text alluded to), but, as pointed out by Margriet Hoogvliet, she "could not personally incarnate royal power as did the kings" and "carefully avoided presenting herself as a great and powerful ruler" (Hoogvliet 2003, pp. 113, 129). An ominous warning is added to this request, as both the salvation of the king's soul and the future of his reign depend on the queen accepting to carry out what is actually a task instituted by God Himself: the fate of the infamous Biblical queen Jezebel, of the Arian empress Justina and of the wicked councilor Haman are all paraded before the eyes of Catherine de Medici, undoubtedly to serve as a poignant reminder of what befell the enemies of God. The image of Esther is invoked in this text as well: but Catherine was in a much more favorable position than the Biblical queen, therefore she would not have any excuse if she failed to act. By using the example of Esther, it might seem that the only thing the author expects from Catherine de Medici is the cessation of the persecution of the Protestants. Yet, his goal is much more ambitious: the queen is to instruct the king in the Reformed faith, so that "all idolatry and abomination are banished from the kingdom" ( Mémoires de Condé 1743, p. 229). At the end, the veiled warning from the main text becomes an impertinent threat: if the king would convert to the Reformation by other means (in other words, without Catherine playing any role in the process), and the queen would not, Charles IX might deprive his mother of her position. The Bible, once again, provides the precedent for what otherwise would seem an almost sacrilegious lack of filial piety: if Catherine would not become a new Esther, then she could become another Maacah, deposed by her grandson, king Asa of Judah (Mémoires de Condé 1743, p. 229). These words basically foreshadow the complete collapse of Catherine's reputation in the eyes of Reformers during the next years, culminating in a veritable "black legend" after 1572. As Jean-Marie Constant pointed out, Catherine's intention was to "attempt to make the two religions coexist and give the Protestants a juridical status", but "it was not imaginable that a prince could accept his subjects to belong to a different religion" (Constant 2002, p. 11). By directing her efforts at pacification in those first years of the reign of Charles IX, Catherine would attract upon herself the ire of both sides and the comparison with Jezebel will be thrown at her from the Catholic circles as well (Jouanna 2009, p. 392).

The exhortation itself is by far the most extended of all the quoted texts and the one which also includes the most numerous Biblical references: in fact, the text is literally rife with them. The assertion of St. Paul that all power came from God is demonstrated by the author by referencing Old Testament history: it is such an evident truth that even pagan kings like Cyrus acknowledged it. The most exemplary figure put forward in the exhortation is King David: his virtue is given shape by his submission to God, which is what interests the author. The text points out, with the help of an extensive quotation from the Bible, a solemn engagement of David to serve God, which is reiterated by his son, Solomon. However, the example which the author proposes to Charles IX as his patron is that of Josias, in light of the similarity of their age when they assumed the throne. It is conspicuous that, when narrating Josias' life, the exhortation insists on his destruction of idols: it is likely an echo of the Protestants' iconoclastic tendencies, as an obvious parallel could be established between the idols of the Old Testament and the "idolatries" of the Catholic Church. The Protestant destruction of relics and other Catholic symbols was one of the strongest arguments for the charges of sedition launched against them and a powerful irritant for the French monarchy: for this reason, Calvin and other pastors, despite their 
distaste for the Catholic reliquary, disapproved of the practice. Denis Crouzet defines the Huguenot iconoclasm as "a phenomenon of reorganization of the sacred space of the kingdom" (Crouzet 2008, p. 196). In her article "Rites of Violence", Natalie Zemon Davis identified the goal of the religious riots of that time as "ridding the community of dreaded pollution" and "many of the acts of violence performed by Catholic and Protestant crowds have $(. .$.$) the character either of rites of purification or of a paradoxical desecration,$ intended to cut down on uncleanness by placing profane things, like chrism, back in the profane world where they belonged" (Zemon Davis 1973, pp. 57-59). In order to achieve this goal, Catholic relics were a primary target for the Protestants. The example of Josias could provide the Protestants with a neat exit from their conundrum: if the king himself took the lead in this matter, then their iconoclasm became sanctioned by the state and was no longer seditious. This was even more necessary since many Protestants simply could not be dissuaded from such actions, despite the possible negative consequences for the Reformation: the cause of this disobedience, in the opinion of Cristopher Ellwood, lay in the fact that "those who absorbed the Reformed teaching were exposed to a powerful critique of the notion that authority stems from an immanental potency and were provided an account of the operation of power that posited a critical distinction between the divine and ultimate source of power and the temporal instrumentalities that claim authority over spiritual and secular affairs" (Ellwood 1999, p. 111). In contrast with Josias, there are the figures of the evil kings who broke the covenant with God, Rehoboam, Jeroboam and Manasseh, in particular: but the purpose of bringing up these examples is didactic, not to threaten. The author of the exhortation obviously did take into consideration the age of Charles IX and that the king was too young to rule: if more ominous warnings were appropriate-even though undiplomatic_-when addressing adults like Henry II or Catherine de Medici, they would have been most unsuitable in a text prepared for a ten-year old monarch. However, using the example of Josias also serves another purpose: Josias had been the son of Amon and the grandson of Manasseh, both monarchs of Judah who had encouraged idolatrous practices. The purpose was to counter the argument of Catholicism having been the ancestral faith of the realm: this claim also had a momentous importance for the kings of France (and not only for them) who were tracing their descent through an uninterrupted line of Catholic monarchs. In fact, Charles IX would soon assert, at the proclamation of his majority in the Parlement of Rouen in 1563, that he had "no intention of approving a new religion, but to reestablish the unity between his subjects, while waiting for a council" (Daubresse 2005, p. 150). Josias, though, was the most poignant Biblical example against preferring the faith of your predecessor kings, which could become corrupted, to the true word of God-and the exhortation was thus suggesting Charles IX take the same path as the pious Biblical king. This corruption of the true faith, which manifested itself in this way during the reigns of the kings of the Old Testament, re-emerged during the Apostolic Age, when Christ and His disciples had to go against more recent tradition, but which was not in accordance with God's will, and finds itself an equivalent in the fierce opposition of the Catholics, clergy and laymen alike, to the Reformation. The duty to God must prevail over any filial obligation and the author does not hesitate to launch an accusation of heresy against the Catholics, by comparing Arianism and the behavior of its adepts to that of "popes, monks and Sorbonnists", who had "concocted a doctrine totally repugnant and against that of the Prophets, Apostles and the ancient saintly Doctors" (Mémoires de Condé 1743, p. 240). Both Christ's words that "one must leave his father and mother" and those of the Apostle (Peter), "that one must obey God rather than men" (Mémoires de Condé 1743, p. 241) are invoked as an argument against the Catholic position that the faith passed from one generation to another must be the true one. When arguing their case, the Catholics often made the point that "they wanted to live and die in the faith of their fathers", like Christophe de Thou, the first president of the Parlement of Paris, asserted in 1563 in a reply to a letter of the king which justified the peace with the Protestants (Daubresse 2005, p. 151), and it was repeated often enough that the Protestants felt the need for a rebuttal. The triumph of Christianity itself, recalls 
the author, was proof of the fallacy of such an argument, as it prevailed by converting the people from their ancient pagan rites, who thus abandoned the faith of their own fathers. The prospect that God might exact punishment on Charles IX for the sins of his forefathers who persecuted the Reformed faith is brought up: the Biblical examples serve both as warning (namely, the sons of Saul, Jeroboam and Ahab) of what might befall Charles IX, but also as comfort (the case of Ezekias and Josias, who avoided such a fate due to their piety). The exhortation basically proposes to Charles IX an alternative (symbolic) lineage: if his immediate ancestors had proven to be deficient in terms of faith, Charles IX could find solace in a (spiritual) descendance from the most acclaimed monarchs of the Bible and of Christian Rome.

The exhortation continues by arguing that, if the clergy was deficient, it was the duty of the king to correct or replace them, an obligation implicit in his office: that is the task which Charles IX must carry out, following in the footsteps of King Josias. The involvement of the king is deemed more necessary because, without his support, idolatry "could never be totally extirpated, if it had taken roots for a long time" (Mémoires de Condé 1743, p. 250). In his attempt to persuade Charles IX, the author argues that the conditions for a (Protestant) reform of the French Church are far more favorable than those which Josias had had to face: in particular, he claims that most of his French subjects "thirsting for their salvation and the glory of God, do not cease to ask for it" (Mémoires de Condé 1743, p. 257). In contrast, any attempt to eradicate the Reformation is doomed to fail and Biblical history, from the time of Jeroboam to the time of the Apostles during the rule of Nero, is brought up as evidence of the faithful's successful perseverance in the face of adversity, with the help of God. More than that, any such attempt would incur significant danger for the king: it is not, though, a veiled allusion to the possibility of rebellion, as the author emphasizes "that it is more fitting for our condition and faith to be killed rather than kill" (Mémoires de Condé 1743, p. 257), but to divine vengeance, although, diplomatically, the text does not press the point too much. Yet, if sedition is not considered, another possible defensive mechanism is envisioned: the prospect of exile, which would deprive the kingdom of valuable subjects and would leave France like "after a great and universal pestilence or a great war" (Mémoires de Condé 1743, p. 260). The way to vanquish heresy is by proving the truth of one's doctrine, in a theological debate, and not by "sword and fire": this is an argument which anticipates the colloquium of Poissy, and the author has no doubt the Protestant pastors will prevail in such an encounter. The argument might seem not very consistent with Calvinism's own history or the teachings of influential theologians like Theodore Beza: Michael Servetus had been executed in 1553 for heresy by the Genevan authorities at Calvin's instigation and Beza had fiercely defended this action. The different relationship between the Reformed faith and the authorities of Geneva and, respectively, France could obviously be taken into account in order to explain for this different attitude: the Genevan magistrates were acting as the secular arm of the Reformed Church, while in France, the Crown was, at best, neutral, at worst, pro-Catholic. Therefore, it was wiser to insist, when addressing the Crown, upon a peaceful solution: this was not an entirely hypocritical and self-interested argument, because the Protestant theologians were genuinely hostile to vigilante justice meted out to heretics. As pointed out by Natalie Zemon Davis, Pierre Viret, one of the most influential Protestant pastors in France, "told his flock that private individuals should never take it upon themselves to stop public scandals under cover of having some 'extraordinary vocation'" (Zemon Davis 1973, p. 65). It is also obvious from the biblical references that the author of the exhortation is not hostile to suppression of "idolatry" by force, as long as such action is legitimate: to be so, it must be undertaken by the proper authorities and, most importantly, must be in accordance with the Word of God. The purpose of a theological debate was to persuade the king, not necessarily the "heretics", who, after the inevitable triumph of the Protestants, could be suppressed in good conscience by the lawful authorities. For the author, since the Catholics seemed to prefer the use of force, it was only with the support of the king that such a debate could have been arranged. In the end, after the example of Josias had been described in 
such detail as a model for Charles IX to emulate, the words of David and of the Book of Wisdom are quoted to remind the young Charles of the traditional duty of kings to serve God and that their power was given to them by the Lord (Mémoires de Condé 1743, p. 265).

In this campaign to persuade the king and the most important figures of the kingdom, the Colloquium of Poissy, from September 1561, has a special place. Called by Catherine de Medici in order to find a possible solution to the religious division of France, through a debate between Catholic theologians and Protestant pastors, it was the first and only time the Protestants had the opportunity to defend their confession of faith in front of the king and the royal family. Theodore Beza had no qualms about antagonizing the Catholic prelates present at the colloquium by attacking the Catholic dogma of transubstantiation, while reasserting the Protestants' desire to obey their king. Hugues Daussy points out that, "in order to better understand Beza's attitude, we must understand the idea which Calvin and his followers had about the colloquium beforehand: in their opinion, if there was one hope, whatever small, to impose the Truth of the Gospel with the help of debates, this would not occur by persuading the prelates, who were lost in advance, but the queenmother, the king and the princes of the blood. Just as happened three decades before, in the Swiss cities of Zürich, Berna and Lausanne, where the magistrates chose the side of the Reformation after a public debate, only a royal decision could accomplish their dream of making Protestantism triumph" (Daussy 2015, p. 255). The colloquium could be considered in a way the culmination of the Protestants' effort to convert the royal family: it is worth remembering that they had directly requested Henry II, four years before, to organize exactly such a debate. The dream was that the king would acknowledge, in the words of Hugues Daussy, "the profound Christian character of the Protestant faith" (Daussy 2015, p. 255): the reality, though, was reflected by the angry reaction of the Catholic clergy to Beza's words attacking the doctrine of transubstantiation. According to Jotham Parsons, "the theological debates demonstrated that irenical Catholic reform, even with strong support from the government, could neither mobilize support among the broader community of Catholic theologians nor reach a meaningful consensus with even relatively conciliatory Calvinists" and the "attempts to reach formulas of concord on the Eucharist and the use of images were in vain, despite being led by the ultraliberal bishop Jean de Monluc of Valence and the Erasmian theologian Claude d'Espence" (Parsons 2004, p. 107). The problem was that neither side was prepared to make any meaningful theological concessions: Calvin had specifically instructed Beza along these lines. As pointed out by Costas Gaganakis, "it was Calvin's declared intention that his theology would present the world with God's truth and his entire polemic production was devoted to the defense of it against dangerous fallacies" and "the defense of God's truth entailed an all-out war against the forces of darkness" (Gaganakis 2006, p. 135) The colloquium fell way short of the hopes of all parties involved: it did not lead to a theological reconciliation, as hoped by Catherine de Medici, nor did it persuade the king and the queen-mother to support the Reformation. In its immediate aftermath, the Protestants did achieve some success through the Edict of Saint-Germain, issued in January 1562, which granted them formal recognition and a limited freedom of worship. This success did not prove durable, though, as the inter-confessional tensions led in March 1562 to civil war.

\section{Conclusions}

In the end, the hopes placed by the Protestants on the conversion of the king of France and all their propaganda full of Biblical references proved to be of no effect. Yet, the Protestants had no choice in the matter in the hopeful period of 1555-1562, when they seriously entertained the idea of converting all of France. As argued by Benjamin Kaplan, toleration was "an embarrassment" and even a sin, because "to the extent that it entailed the abandonment of hopes for the triumph of the one true faith, it clashed directly with the eschatological teachings of all the Christian churches" and thus suffered "from a basic illegitimacy" (Kaplan 2007, p. 143). The civil wars saw the Protestants and the Crown pitted on opposite sides: although they tried for a very long time to argue that they were 
not fighting against the king, and they were capable of maintaining this fiction especially during the first civil war of 1562-1563, due to the fact that the leadership of the Catholic forces was assumed by a trio of powerful Catholic potentates, François de Guise, the constable Anne de Montmorency and the marshall of Saint-André, it became harder to keep up this facade once the Crown took a more active role in the fighting, after 1567.

The tone used by the Protestants towards the king also started to slowly shift from reverential to more defiant: the texts urging him to convert started to make room for others which seriously considered placing limits on royal power, only for this rhetoric to fully bloom after 1572 into the so-called "monarchomach" literature, advocating the overthrowing of tyrannical kings. The biblical references returned once more, but this time their use was completely different: instead of exalting the figure of a providential king who would restore his people to the faith of God, they emphasized the fallacies and the abuses of the biblical monarchs. The idea of the king having obligations imposed upon him was reiterated: but, in the monarchomach texts, what had been before a relationship only between kings and God, of which the people was a passive beneficiary, became a fully-fledged pact between God, king and people, which granted the latter the right to correct and castigate an errant king. The character of the obligations changed as well: the texts from the period 1555-1562 focused mostly on the king's religious duty, which was the capital issue deciding the assessment of a reign, and they urged him to convert his realm in imitation of the monarchical religious reformers of the Old Testament. The monarchomach literature, though, abandoned this confessional approach: instead, all the king's actions became subject to scrutiny and he could be considered a tyrant liable to deposition for purely secular policies, but which were contrary to the well-being of the subjects. This reflects the new attitude of the Protestants after 1572, who, in the new circumstances, were more interested in finding a way to co-exist in France with the Catholic majority and, therefore, had to co-opt those Catholic elements dissatisfied with royal policy.

The conversion of the king of France to the Reformation, which the Protestants hoped for and even believed in during the period 1555-1562 (belief which persisted to a lesser extent, albeit fading away slowly, until 1572), remained only a pipedream because it never took into consideration the political realities: the authors of these texts were all Protestant theologians, all deeply committed to their dogma, in whose view the word of the Gospel, as they interpreted it, should have been enough to persuade the king. They never really took into account how strong Catholic sentiment was in France and how deeply connected the French monarchy was to the Catholic Church and its rituals. This would be clearly proven several decades later, when, much to Beza's dismay, Henry de Navarre, the most prominent Protestant in France, had to convert to Catholicism in order to overcome the opposition to his ascent to the throne of France.

Funding: This work was supported by a grant of the Ministry of Research, Innovation and Digitization, CNCS/CCCDI-UEFISCDI, project number PN-III-P1-1.1-TE-2019-0499, within PNCDI III.

Institutional Review Board Statement: Not applicable.

Informed Consent Statement: Not applicable.

Data Availability Statement: Not applicable.

Conflicts of Interest: The author declares no conflict of interest.

\section{References \\ Primary Source}

de la Planche, Louis Régnier Sieur. 1576. Histoire de l'estat de France, Tant de la République que de la Religion: Sous le règne de François II.

\section{Secondary Sources}

Babelon, Jean-Pierre. 2010. Henri IV et la Réforme. Bulletin de la Société de l'Histoire du Protestantisme Français 156: 595-606. 
Benedict, Philip. 2002. The Wars of Religion 1562-1598. In Renaissance and Reformation France 1500-1648. Edited by Mack P. Holt. Oxford and New York: Oxford University Press.

Bryson, David. 1999. Queen Jeanne and the Promised Land. Dynasty, Homeland, Religion and Violence in Sixteenth-Century France. Leiden and Boston: Brill.

Carroll, Stuart. 2009. Martyrs and Murderers: The Guise Family and the Making of Europe. Oxford and New York: Oxford University Press.

Christin, Olivier. 1999. From Repression to Toleration: French Royal Policy in the Face of Protestantism. In Reformation, Revolt and Civil War in France and the Netherlands 1555-1585. Edited by Philip Benedict, Guido Marnef, Henk van Nierop and Marc Venard. Amsterdam: Royal Netherlands Academy of Arts and Sciences.

Constant, Jean-Marie. 2002. Les Français Pendant les Guerres de Religion. Paris: Hachette Littératures.

Crespin, Jean. 1887. Histoire des Martyrs Persecutez et mis a Mort pour la Vérité de l'Évangile, Depuis le temps des Apostres Jusques à Présent (1619). Édition nouvelle précédée d'une introduction par Daniel Benoit et accompagnée de notes par Matthieu Leliévre. Tome Deuxième. Toulouse: Société des Livres Religieux.

Crouzet, Denis. 2008. Dieu en ses Royaumes. Une Histoire des Guerres de Religion. Seyssel: Champ Vallon.

Daubresse, Sylvie. 2005. Le Parlement de Paris ou la Voix de la Raison (1559-1589). Geneva: Librairie Droz.

Daussy, Hugues. 2015. Le Parti Huguenot: Chronique d'une Désillusion (1557-1572). Geneva: Librairie Droz.

Ellwood, Christopher. 1999. The Body Broken: The Calvinist Doctrine of the Eucharist and the Symbolization of Power in Sixteenth-Century France.. Oxford and New York: Oxford University Press.

Gaganakis, Costas. 2006. Religious Zeal and Political Expediency on the Eve of the French Wars of Religion. Historein 6: 134-43. [CrossRef]

Heller, Henry. 1986. The Conquest of Poverty: The Calvinist Revolt in Sixteenth-Century France. Leiden: Brill.

Hochner, Nicole. 2010. Imagining Esther in Early Modern France. Sixteenth Century Journal 41: 757-87.

Hoogvliet, Margriet. 2003. Princely Culture and Catherine de Médicis. In Princes and Princely Culture 1450-1650. Volume One. Edited by Martin Gosman, Alasdair MacDonald and Arjo Vanderjagt. Leiden and Boston: Brill.

Jedin, Hubert. 1963. A History of the Council of Trent: The Struggle for the Council. London and Edinburgh: Thomas Nelson and Sons.

Jouanna, Arlette. 2009. La France du XVI Siècle, 1483-1598. Paris: Presses Universitaires de France.

Kaplan, Benjamin J. 2007. Divided by Faith: Religious Conflict and the Practice of Toleration in Early Modern Europe. London and Cambridge, MA: Harvard University Press.

Kingdon, Robert M. 2007. Geneva and the Coming of the Wars of Religion in France, 1555-1563. Geneva: Librairie Droz.

Knecht, R. J. 2014. Catherine de' Medici. London and New York: Routledge.

Mémoires de Condé, ou Recueil pour Servir à L'histoire de France. 1743. Tome Second. London: Claude du Bosc et Guillaume Darrès.

Parsons, Jotham. 2004. The Church in the Republic. Gallicansm \& Political Ideology in Renaissance France. Washington, DC: The Catholic University of America Press.

Racine St-Jacques, Jules. 2012. L'Honneur et la foi: Le Droit de Résistance Chez les Réformés Français (1536-1581). Geneva: Librairie Droz.

Ramsey, Ann W. 1999. Liturgy, Politics, and Salvation: The Catholic League in Paris and the Nature of Catholic Reform, 1540-1630. Rochester: University of Rochester Press.

Roelker, Nancy Lyman. 1996. One King, One Faith: The Parlement of Paris and the Religious Reformations of the Sixteenth Century. Berkeley and Los Angeles: University of California Press.

Schmidt, C. F., ed. 1882. Poésies Huguenotes du Seizième Siècle. Strasbourg: Librairie Académique.

Tallon, Alain. 2002. Conscience Nationale et Sentiment Religieux en France au XVIe Siècle. Essai sur la Vision Gallicane du Monde. Paris: Presses Universitaires de France.

Trocmé, Étienne. 1959. Une Révolution mal conduite. A propos d'un centenaire et d'un livre. Revue d'Histoire et de Philosophie Religieuses 39: 160-68. [CrossRef]

Wylie Sypher, G. 1980. 'Faisant ce qu'il leur vient a plaisir': The Image of Protestantism in French Catholic Polemic on the Eve of the Religious Wars. Sixteenth Century Journal 11: 59-84. [CrossRef]

Zemon Davis, Natalie. 1973. The Rites of Violence: Religious Riot in Sixteenth-Century France. Past E Present 59: 51-91. 